\title{
Bleylebenové - nizozemský rod v dějinách a kultuře habsburské monarchie
}

\section{JAN KILIÁN}

Kilian, Jan: The Bleyleben - A Dutch Family in the History and Culture of the Habsburg Monarchy

This article focuses on the as yet unprocessed history and genealogy of members of the originally Dutch family Regniers of Bleyleben who connected their fates with the countries of the Central European Habsburg monarchy no later than in the beginning of the $17^{\text {th }}$ century. They excelled especially in the military field but also in politics, science and legal disciplines. Furthermore, they left behind a significant cultural legacy (the pilgrimage church in Bohosudov, secular architecture and physical heritage in the form of archival documents or museum exhibits).

Key Words Regniers of Bleyleben; Nobility; Genealogy; Habsburg Monarchy; Early Modern Time; Culture

doi.org/10.15452/Historica.2020.11.0009

Contact Univerzita Hradec Králové; jankilian@email.cz

Historie rodu Regniersů/Regnerů z Bleylebenů je stará možná již více než sedm set let, a přitom stále nedopsaná, jelikož jeho příslušníci nadále žijí, i když již dávno mimo své někdejší domovy a zcela civilním životem. Na počátku 17. století se dva Bleylebenové, bratři, vydali za kariérou z rodného Španělského Nizozemí, dnešní Belgie, do středoevropské habsburské monarchie. Starší z nich dosáhl v císařské armádě plukovnického patentu, stal se říšským svobodným pánem, dvorským válečným radou a majitelem dvou severočeských panství i reprezentativního domu v Praze na Malé Straně. Novou českou linii však nezaložil, protože jeho jediný syn zemřel násilnou smrtí ještě před otcovým skonem. Naproti tomu mladší z bratrů takového uznání a prestiže od císaře nedosáhl a žil ve velmi skromných podmínkách, stejně jako několik generací jeho potomků, nicméně vstoupil do dějin coby předek všech pozdějších, tj. i současných Bleylebenů. Jeden z nich se stal na počátku 20. století dokonce zemským prezidentem v Bukovině a moravským místodržícím, jiní měli vysoké funkce v armádě, další se proslavili v oblasti vědy, kultury či práva. Z Čech se rozšíríli do Horní Falce, na Moravu, do Uher i do Dalmácie. Přesto pozornost evropské historiografie dosud nepřitáhli. Následující popisný, nikoli analytický prríspěvek si samozřejmě klade jen omezené cíle - podat přehled o dosud nezpracované bleylebenovské genealogii, upozornit na vynikající osobnosti z tohoto rodu a poukázat na jejich zajímavý odkaz.

Regniersové z Bleylebenu se hlásí k původu od středověkého nizozemského šlechtice Johannese de Blydeleben, připomínaného údajně v roce $1282 .{ }^{1}$ Žili podle všeho dlouhodobě ve Flandrech, kde se zřejmě ve vojenských službách uplatnil ve druhé polovině 
16. století i jménem nám neznámý otec Alexandra a Jakuba Bleylebenů. ${ }^{2}$ Oba zmínění bratři, neochvějní katolíci, se z Nizozemí vydali na východ a své služby nabídli habsburským císařům, přičemž se možná zapojili do probíhající patnáctileté války středoevropské monarchie s Turky. Zvláště u staršího Alexandra (1578/1579-1649) je to více než pravděpodobné. V roce 1610 totiž od císaře Rudolfa II. získal, i společně s bratrem, potvrzení šlechtického stavu na základě svých služeb habsburskému domu, nepochybně na vojenském poli. ${ }^{3}$ Začínal přitom doslova od píky, v době vypuknutí třicetileté války byl teprve hejtmanem. Za ženu měl od roku 1615 českou šlechtičnu Annu Marii Pichlovou z Pichelberka, s níž žil v Praze v jednom z malostranských domů, vlastní panství tehdy manželé neměli. Během českého stavovského povstání zachovali věrnost Habsburkům a museli se uchýlit do exilu. Po návratu však Alexandr Bleyleben prodělal vskutku závratnou kariéru. Začala se psát od chvíle, kdy velel eskortě ${ }^{4}$ která od sasko-českých hranic transportovala do vězení v Praze Jáchyma Ondřeje Šlika, jednoho z předáků českých rebelů, popraveného při hromadné exekuci na Staroměstském náměstí, resp. spíš od chvíle, kdy se flanderský dobrodruh přidal pod prapory Albrechta z Valdštejna. S jeho vojskem prodělal celou řadu bitev a přes hodnosti hejtmana a kapitána, nejvyššího strážmistra, nejvyššího lajtnanta (podplukovníka) se propracoval až do šarže plukovnické. ${ }^{5}$ Velmi si polepšil z majetku konfiskovaného českým povstalcům - nejprve šlo o prostorný dům v ulici pod Pražským hradem (Nerudova ulice, dům/palác je dnes rumunskou ambasádou), posléze o severočeské panství Soběchleby, k němuž za několik dalších let ještě přikoupil i Všebořice (dnes součást Ústí nad Labem). ${ }^{6}$ Tím se stal pánem hned dvou zámků a pustnoucího hradu Kyšperka u Krupky. V době války monarchie se Saskem (1631-1635) proslul smělou akcí, kdy na vlastní pěst podnikl pustošivý výpad do saského pohraničí jako odvetu za vyplenění svých českých statků. ${ }^{7}$ Po skončení aktivní služby byl jedním z dvorských válečných radů a udržoval čilé kontakty s čelnými domácími aristokraty. Patřil kuprríkladu k oblíbeným hostům pražského arcibiskupa, kardinála Arnošta Vojtěcha z Harrachu, kterého v kartách připravil o nemalou částku peněz. ${ }^{8}$ Společně se ženou také náležel k velkým podporovatelům jezuitů a jimi provozovaného poutního kostela v Bohosudově na svém soběchlebském panství. Na sklonku svého života ovšem prožil skutečné martyrium. V létě roku 1648 Prahu přepadla švédská vojska, opanovala její levý břeh a mezi mnoha dalšími paláci a domy vyplenila i Bleylebenovo obydlí. Jeho a jeho rodinu Švédové uvěznili a požadovali vysoké výkupné. ${ }^{9}$ Snad s pověřením peníze obstarat byl ze zajetí propuštěn jediný Alexandrův syn Karel Maxmilián, který se vydal na rodinné statky v severních

\footnotetext{
2 Státní oblastní archiv (dále SOA) Litoměřice, pracoviště Děčín, fond Rodinný archiv (dále RA) Clary-Aldringenů, inv. č. 105, karton 43 - Alexandr Regniers z Bleylebenu Janu Aldringenovi, nedat. (cca 1630).

3 Österreichisches Staatsarchiv, Allgemeines Verwaltungsarchiv Wien, Adelsarchiv, Hofadelsakt, Regner (Regnier) von Bleyleben, Alexander, Jakob, Brüder, 1610.

4 LUKÁŠEK, Josef: Jáchym Ondřej hrabě Šlik. Praha 1913, s. 203.

5 Bylo to zvláště v počátečních fázích třicetileté války, o nichž nejnověji pojednává FUKALA, Radek: Konec zimního království a poslední ohniska odporu. České Budějovice 2016. Např. na s. 56 a 57 zde autor zmiňuje významný Bleylebenův podíl při obléhání jihočeského Tábora.

6 Stručný přehled jeho zisků podává BÍLEK, Tomáš V.: Dějiny konfiskací v Čechách po r. 1618, I. Praha 1882, s. $95,257,262,383$.

JAHNEL, Carl: Der dreissigjährige Krieg in Aussig und Umgebung, 1-3. Prag 1903-1904, s. 388-389.

8 Srov. KELLER, Katrin - CATALANO, Alessandro (Hg.): Die Diarien und Tagzettel des Kardinals Ernst Adalbert von Harrach (1598-1667), I-VII. Wien - Köln - Weimar 2010. Např. svazek IV, s. 803.

9 Národní archiv (dále NA) Praha, fond Stará manipulace, inv. č. 247, kart. 171, sign. B 65/2.
} 
Čechách. Tady se však dostal do zbytečného konfliktu se saskými vojáky a byl jimi zabit. ${ }^{10}$ Zarmoucený otec jej nepřežil ani o rok. Místo svého posledního odpočinku nalezl v pichlovské hrobce v kostele sv. Tomáše v Praze na Malé Straně. ${ }^{11}$

Uvedený Karel Maxmilián (1616-1648) byl bez nadsázky enfant terrible. Měl sice podle všeho zhruba o rok mladšího bratra, jenže ten zesnul asi nedlouho po svém narození, takže jeho sourozenec byl vychován jako jedináček. A to jedináček starostlivými rodiči rozmazlovaný. Vyrůstal v Praze na Malé Straně, možná jako odchovanec jezuitů. Na finančně náročnou kavalírskou cestu ${ }^{12}$ coby zakončení svého vzdělávacího procesu ale zamíríl až s velkým zpožděním, v době, kdy mu bylo kolem osmadvaceti let. Vydal se do Itálie a mimo jiné navštívil i Řím... A toužil ještě po Neapoli. ${ }^{13}$ Jeho otec, sám hovořící vlámsky, francouzsky, německy, italsky a možná též španělsky (původ ve Španělském Nizozemí) a česky (dlouhý život v Čechách a česká manželka), se svému potomkovi kromě zeměpisného a společenského rozhledu jistě snažil zajistit i zlepšení jeho jazykových dovedností. Nutno ovšem podotknout, že mladý Bleyleben měl již předtím na svědomí několik výstřelků a provokací, z nichž jedna záležitost skončila při skupinové šarvátce v Praze tragicky, jiná zraněním malého chlapce a další málem soubojem s jistým šlechticem. ${ }^{14}$ A to ještě ve Vídni koncem roku 1639 putoval do vězení, protože se chtěl vyhnout karanténě, která tehdy kvůli moru platila pro příchozí z Prahy, a tak se vydával za někoho jiného. ${ }^{15} \mathrm{~V}$ tu dobu už byl ženatý s Annou Žofií Eleonorou Příchovskou, s níž si však přiliš nerozuměl a potomky s ní žádné nezplodil. Cesta do Itálie Karla Maxmiliána nijak nezkulturnila. Po návratu ze zahraničí pobýval častěji na otcovském zámku v Soběchlebech, kde se jednou se svou čeledí musel, v časech stále probíhající třicetileté války, bránit po verbálním incidentu útoku císařských (sic!) vojáků. ${ }^{16}$ Kromě vlastních poddaných měli s mladým Bleylebenem zvláště špatnou zkušenost měštané z Krupky, města sousedícího se soběchlebským panstvím. Pro autora unikátních pamětí, tamního koželuha Michela Stüelera byl Karel Maxmilián mordýřem, cizoložníkem, ochlastou a skutečným epikurejcem. ${ }^{17}$ Že miloval alkohol (a lov a lovecké psy), je z pramenů dostatečně známo, stejně jako to, že se dopustil zločinu vraždy na svém vlastním soběchlebském úředníkovi, písaři Hansi Broschem, a to přímo v Krupce na návštěvě u faráře počátkem roku 1647. Samozřejmě, v silně podnapilém stavu. Téhož faráře se přitom sotva o rok později na svém sídle chystal vyhodit z okna za napomenutí ohledně dodržování půstu, neštěstí na poslední

\footnotetext{
10 KILIÁN, Jan (ed.): Paměti krupského koželuha Michela Stüelera (1629-1649). Teplice - Dolní Břežany 2013, S. 697 .

11 NA Praha, fond Wunschwitz, inv. č. 75, kart. 4- Bleileben.

12 Kavalírské cesty patří ve středoevropské historiografii k mimořádně populárním tématům a výčet relevantních prací by byl značně obsáhlý. Vybírám proto jen jednu jedinou, která reprezentuje edici deníku jednoho takového kavalíra a fundovanou doprovodnou studii s bohatým výčtem příslušné odborné literatury: HOJDA, Zdeněk CHODĚJOVSKÁ, Eva (red.): Heřman Jakub Černín na cestě za Alpy a Pyreneje, I-II. Praha 2014.
}

13 KELLER, K. - CATALANO, A. (Hg.): Die Diarien, V, s. 57 - Harrachův zápis z 24. listopadu 1644, že do Říma právě dorazil mladý Bleyleben a že vyjádřil přání, když už byl tak daleko, vidět ještě Neapol. Zda se do ní nakonec skutečně vypravil, není známo.

14 Viz např. NA Praha, fond Stará manipulace, inv. č. 247, sign. B 65/9, kart. 172. Celý fascikl se týká sražení dítěte Bleylebenem v Praze a jeho záměru vyvolat souboj s jiným šlechticem.

15 KELLER, K. - CATALANO, A. (Hg.): Die Diarien, II, s. 436.

16 Státní oblastní archiv Zámrsk, fond Rodinný archiv Piccolominiů, inv. č. 29193, Mikrofilm 89, Karel Maxmilián z Bleilebenu Ottaviovi Piccolominimu, rok 1643.

17 KILIÁN, J. (ed.): Paměti, s. 697. 
chvíli zabránil jiný přítomný šlechtic. ${ }^{18}$ Pokud jde o cizoložství, v Krupce se tehdy šuškalo, že měl Bleyleben s nějakou místní dívkou dvě nemanželské děti, což ovšem nelze věrohodně prokázat. ${ }^{19}$ Jiný než násilný konec život tohoto neklidného muže snad ani vzít nemohl. Pohřben byl, na rozdíl od obou rodičů, v bohosudovském kostele Bolestné Panny Marie, nedaleko místa svého skonu. Ačkoli původní svatostánek dostal posléze vrcholně barokní podobu a z toho původního mnoho nezůstalo, Bleylebenův náhrobní kámen se dochoval v ambitu v jedné z kaplí, která je nazývána kaplí bleylebenovskou. Kamenicky kvalitně provedená, na šiřku orientovaná sepulkrální památka nese v horní části zápis o úmrtí Karla Maxmiliána a ve spodní tři znaky - dva patří Bleylebenům (otci a synovi) a třetí, prostřední, rodu Pichlů z Pichelberka, jehož př́islušnicí byla matka zemřelého.

Anna Marie Bleylebenová z Pichelberka (kolem 1595-1665) pocházela z drobné české vladycké rodiny. Byla dcerou nejvyššího dvorského poštmistra Jiřího Pichla z Pichelberka a jeho ženy Hedviky Robmhápové ze Suché. Otci Anny Marie patřila dvě menší středočeská panství, Chrustenice a Vysoký Újezd, obě s rytířskými tvrzemi, vyrostla však v pražském domě na Malostranském náměstí. ${ }^{20}$ Po smrti obou rodičů se v roce 1615 provdala za Alexandra Regnierse z Bleylebenu. Většinu svého života strávila v české metropoli, aniž bychom o ní tehdy věděli více než drobnosti - třeba o jejích společenských návštěvách, které absolvovala se svým chotěm. Po synově, a zvláště po manželově smrti (1649) se nicméně musela postarat o rodinný majetek, protože se z ní stal shodou okolností jak poslední výhonek rodu Pichlů, tak na dlouhou dobu poslední nositelka bleylebenovského jména v českých zemích. Bylo její zásluhou, že z nejhoršího vyvedla nejen Švédy zpustošený malostranský dům v dnešní Nerudově ulici, ale také obě válkou vylidněná severočeská panství Soběchleby a Všebořice. I navzdory tomu, že se tu nevyhnula nepoctivosti svého vrchního úředníka, kterého nakonec dala za velké zpronevěry uvěznit. Navlékla černý vdovský šat, jak o tom svědčí všechny tři její známé portréty, ${ }^{21}$ a ještě usilovněji začala podporovat jezuity i jiné církevní řády a instituce. Už ve 20 . letech 17 . století bohosudovskému kostelu věnovala cenný, umělecky propracovaný stř́ibrný kalich a dodnes dochované, perlami a zlatem vyšívané mešní roucho. Svou závětí ${ }^{22}$ odkázala mnoho tisíc zlatých na zbožné účely, panství Soběchleby bohosudovskému kostelu Bolestné Panny Marie, spravovanému jezuity, malostranský dům a panství Všebořice spřízněnému českému hraběti Maxmiliánovi Valentinovi z Martinic. Ten jí po smrti na zámku v Soběchlebech a převozu těla do Prahy také vypravil velkolepý pohřeb v malostranském kostele sv. Tomáše. ${ }^{23}$

18 Tamtéž, s. 639 (vražda Broscheho) a 683 (agrese vůči faráři).

19 NA Praha, fond Stará manipulace, inv. č. 247, sign. B 65/1, kart. 171. Dne 3. února 1647 činí v Litoměřicích litoměřičtí krajští hejtmani Maxmilián z Aldringenu a Gottfried Konstantin ze Salhausenu českým místodržícím zprávu ohledně vraždy obilního písaře a nepravostí na ženách spáchaných Karlem Maxmiliánem z Bleylebenu. Pokud jde o nepravosti na ženách, můžou říci jen to, co o něm v obci koluje, totiž že měl zplodit s nějakou svobodnou dívkou dvě děti, které jsou dosud naživu. Pokud se dovědí v této věci více, budou místodržící informovat.

20 O rodu Pichlů a mládí Anny Marie podrobně KILIÁN, Jan: Pichlové z Pichelberka a sourozenecký spor o dědictví. Bohemiae Occidentalis Historica 6, 2020, č. 1 (v tisku).

21 Jeden z portrétů Anny Marie Bleylebenové kdysi visel v bohosudovském jezuitském semináři, ale je dnes nezvěstný, stejně jako jeho pendant s podobiznou Alexandra Regnierse z Bleylebenu. Fotografie obou obrazů však byly otištěny v článku UMLAUFT, Franz Josef: Alexander Regniers und Anna Maria Bleileben auf Sobochleben und Schöbritz. Beiträge zur Heimatskunde des Aussig-Karbitzer Bezirkes 15, 1935, s. 49-56. Druhý z portrétů je uložen v depozitáři Litoměřického biskupství v Litoměřicích. Třetí, takřka identický s druhým (kopie?), byl vydražen před několika lety soukromým sběratelem během aukce v pražském Mánesu a je dnes jeho privátním majetkem.

22 Opis závěti Anny Marie z Bleylebenu je uložen rovněž in: NA Praha, fond České gubernium - exjezuitika, inv. č. 597, sign. 717, kart. 89 (nadace a pense bývalé rezidence v Bohosudově).

23 KELLER, K. - CATALANO, A. (Hg.): Die Diarien, VII, s. 629 (zápis z 20. května 1665). 
Bohosudovský chrám se stal nejtrvalejším pomníkem rodu Bleylebenů. Počátky jednoho z nejvýznamnějších severočeských poutních míst se vztahují k tradovanému pobití německých účastníků kř́žové výpravy proti husitům, která skončila u blízkého Ústí nad Labem. K tomuto vedlejšímu střetu známé bitvy mělo dojít v sousedství Krupky u tvrze zvané Starý Dvůr, posléze součásti Bohosudova. Legenda přitom pracuje také s jinou verzí - z kláštera v severočeském Světci u Duchcova před husitskými válečníky prchaly tamní jeptišky, i se soškou Panny Marie Bolestné, kterou z klášterního kostela zachránily. U Krupky ji schovaly do jedné lípy, ale už ji nevyzvedly. Až později se jedné místní děvečce u stromu zjevila Panna Marie a soška byla po ohledání nalezena. ${ }^{24}$ Bud' jak bud', vznikla zde kaple, k níž postupně proudilo větší a větší množství poutníků, takže ji už začátkem 16. století nahradil menší kamenný kostel. V předbělohorské době, kdy se celé okolní obce stávaly luterskými, zájem o svatostánek upadal. To se ale změnilo poté, co jeho správu převzali jezuité z nově založené koleje v Chomutově. Ti zdejší kult usilovně podporovali a z Bohosudova, tehdejšího Mariaschein (resp. Mariascheune), udělali přitažlivý bod pro katolickou minoritu ze širokého okolí. Po bitvě na Bílé hoře (1620) nastal obrovský rozvoj lokality, která sehrála velmi důležitou roli v procesu probíhající rekatolizace. Kostel záhy nestačil, bylo zapotřebí vybudovat větší. Za bojů třicetileté války to ale nebylo dost dobře možné, takže se s úkolem započalo až po vestfálském míru (1648). S pomocí paní Bleylebenové se jezuité v Bohosudově usídlili natrvalo, když tu nejprve otevřeli svou rezidenci a pak i seminář pro studenty. Kostel obklopil ambit s věncem raně barokních kaplí, pojmenovaných po jejích budovatelích a dobrodincích - včetně paní Bleylebenové. Ta se již nemohla dočkat vzniku velkolepého chrámu, jemuž jeho současnou podobu až na počátku 18. století vtiskli slavní litoměřičtí stavitelé italského původu, Giulio a Octavio Broggiové. Finančně náročnou stavební akci však umožnil především její velkorysý odkaz. ${ }^{25}$

Jakub Regniers z Bleylebenu přišel do středoevropské habsburské říše z nizozemských zemí společně se svým starším bratrem Alexandrem za vlády císaře Rudolfa II. a po vykonání určitých služeb vládnoucí dynastii se společně se svým zasloužilejším sourozencem mohl od roku 1610 těšit $\mathrm{z}$ potvrzení rytířského stavu s platností pro celou monarchii i Řišsi. ${ }^{26}$ Můžeme se pouze ptát, o jaké služby v jeho případě vlastně šlo, zda o vojenské, či o byrokratické, př́ípadně ještě jiné. Stejně jako u Alexandra můžeme s vysokou mírou pravděpodobnosti očekávat oblast vojenství, tím spíš, že se několik zdrojů, byt' nikoli primárních, shoduje na jeho pozdější př́itomnosti ve vojsku Albrechta z Valdštejna. To tvrdil i jeho potomek Oktavián Regner, který ve svém mládí během studií pátral po rodových kořenech. ${ }^{27} \mathrm{~V}$ Doerrově genealogické sbírce se kromě toho uvádí i údajné Valdštejnovo kmotrovství Jakubova syna Tomáše. Mělo se tak stát začátkem ledna 1625 v západočeském Svojšíně. ${ }^{28}$ Bohužel, verifikace je v podstatě nemožná, svojšínské matriky totiž začí-

\footnotetext{
$24 \quad$ Festschrift zum 500jährigen Jubiläum des Wallfahrtsortes Mariaschein. Mariaschein 1925, s. 8.

25 K Bohosudovu mj. MILLER, Joannes: Historia Mariascheinensis, Brüx 1769 nebo HALLWICH, Hermann: Die Jesuitenresidenz Mariascheune („Mariaschein“) in Böhmen. S. l. s. d.

26 Österreichisches Staatsarchiv, Allgemeines Verwaltungsarchiv Wien, Adelsarchiv, Hofadelsakt, Regner (Regnier) von Bleyleben, Alexander, Jakob, Brüder, 1610.
}

27 Knihovna Prácheňského muzea v Písku, sign. PK 12918, REGNER VON BLEYLEBEN, Octavian: Lebensaufzeichnungen. Nedat. strojopis, s. 1.

28 SOA Litomeřice, pracoviště Děčín, fond RA Thunů, Doerrova genealogická sbírka, sign. VII/859 - Regner von Bleileben. 


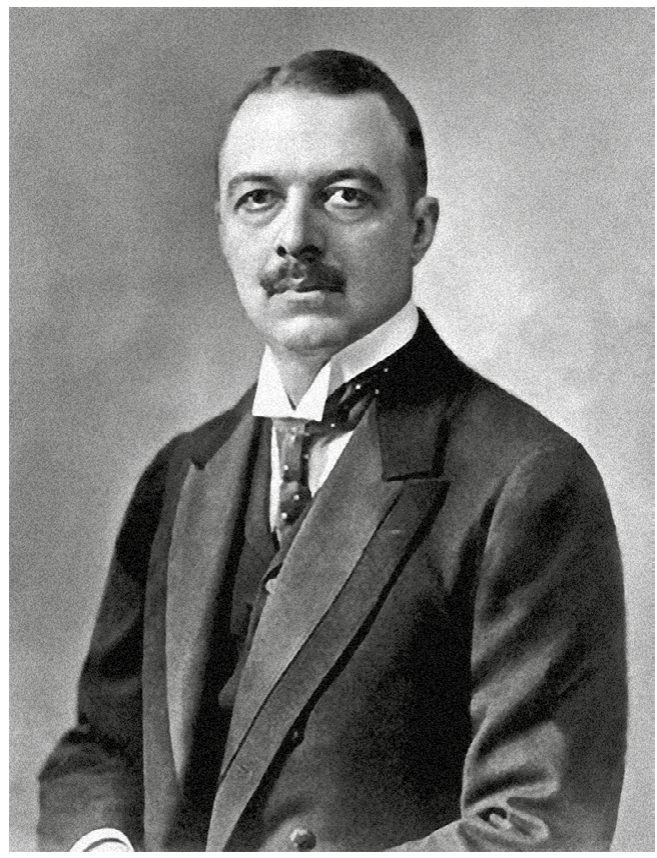

Obr. 1: Oktavián Regner z Bleylebenu. Foto J. Kilián.

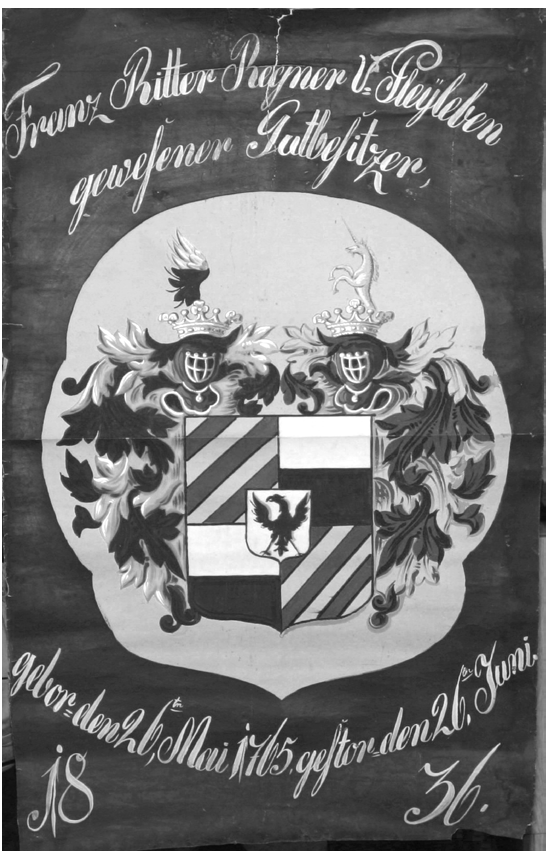

Obr. 2: Pohřební štít Františka z B. s erbem Bleylebenů. Sbírky Prácheňského muzea v Písku.

nají až o několik let později. ${ }^{29} \mathrm{~V}$ armádě se Jakub mohl záhy specializovat na logistiku, na samém konci třicetileté války totiž byl již vrchním proviantním komisařem. Vzápětí, měsíc po uzavření vestfálského míru, získal od císaře Ferdinanda III. ujištění o udělení českého inkolátu pro př́pad, že by se chtěl v zemi usadit. O pouhé tři týdny později (13. prosince 1648) měl také skrze intimaci královské české dvorské kanceláře obdržet potvrzení starožitného rytířského stavu, současně se znakem, který pak jeho potomci nosili i nadále a jenž se shodoval s polepšeným erbem jeho bratra Alexandra. To mohlo souviset s nedávným úmrtím Alexandrova jediného syna Karla Maxmiliána, protože nyní již bylo jasné, že bleylebenovský rod bude pokračovat výhradně Jakubovými potomky. Jenomže Jakubovy kroky vedly do hornofalckého města Furth im Wald, lokality přímo na hranici s Českým královstvím. Z povolení císaře Leopolda I. k vystěhování (Auswanderung) z 3. řijna 1657 vyplývá, že Jakub byl ženatý s Evou Hénin (Hennin)-Liétard de Bossu a měl s ní výše zmíněného syna Tomáše, který se 7. září 1653 ve Furthu oženil s jistou Annou, neznámého príjmení. ${ }^{30}$

Jméno Jakubovy manželky by nám nemělo uniknout. Eva Hénin-Liétard de Bossu byla př́islušnicí jednoho z nejpřednějších flanderských rodů (což je samo o sobě další indicií i k původu Bleylebenů) s vazbami do nejvyšších příček evropské aristokracie, který na území současné Belgie vynikl jak na vojenském, tak na politickém kolbišti a dotáhl to až k titulu princů z Chimay. Maxmilián I. z Hénin, třetí vévoda z Bossu (1542-1578),

29 SOA Plzeň, Sbírka matrik západních Čech, Svojšín 01 - Narození, oddaní, zemřelí 1633-1667.

30 Státní okresní archiv (dále SOkA) Písek, fond RA Bleylebenů, inv. č. 1 - rodokmen mladší větve Bleylebenů. 
byl nejprve španělským místodržícím několika nizozemských provincií a vojevůdcem, po zajetí a propuštění však přešel do služeb republikánů a válčil proti španělským armádám vedeným slavnými Alexandrem Farnesem či Donem Juanem d’Austria, lepantským vítězem, kterého porazil v bitvě u Rijmenamu (1578). Nedlouho po ní však předčasně zemřel. Jeho synovec Maxmilián II. z Hénin, pátý vévoda z Bossu (1580-1628), připadající v úvahu jako otec, starší bratr nebo strýc Bleylebenovy manželky Evy, byl oddaným habsburským služebníkem, neochvějným katolíkem, nositelem Řádu Zlatého rouna, guvernérem města Béthune... a plukovníkem u dělostřelectva. I tudy mohla vést cesta ke vzájemnému sblížení jeho př́buzné s Jakubem, ačkoli šlo o sňatek bez nadsázky morganatický. Pro Alexandrova mladšího bratra byla Eva každopádně vynikající partií. ${ }^{31}$ Pokud $\mathrm{v}$ tu dobu ještě žila, muselo pro ni být přesídlení do Furthu a život na úrovni měštanských vrstev velkou ránou pro její společenskou prestiž. Neznáme bohužel datum ani úmrtí jejího, ani Jakubova.

Jejich syn Tomáš žil v pohraničním falckém městě také - a stejně tak i jeho v roce 1656 narozený mužský potomek Ondřej/Andreas. Ten se sice už krátce před svými dvacátými narozeninami v rodném Furthu oženil s Magdalenou Heimerlovou, ale až začátkem roku 1693, po sedmnácti letech od uzavření (prvního?) manželství, se tu dočkal svého dědice Jiř́iho Baltazara. S Jiřím Baltazarem se Jakubova linie vrátila do Čech, když se tento dvaatřicetiletý Bleyleben v Poběžovicích, tehdejším Ronšperku, oženil s Kateřinou Ubelovou, ovdovělou Praunovou. Mohlo jít o místní měštanku nebo snad o příslušnici fraucimoru poběžovické vrchnosti, což by patrně osvětlil hlubší pramenný průzkum. Ženich sňatkem s vdovou očividně získal její nemovitost a v Poběžovicích už zůstal. Jeho osudy byly nepochybně barvité - jestliže skutečně sloužil pod Evženem Savojským (1663-1736), ${ }^{32}$ vydal se z bavorské Horní Falce do habsburského žoldu a mohl prodělat už závěr válek o španělské dědictví a následně první válku císaře Karla VI. s Turky v letech 1716-1718, ukončenou požarevackým mírem. Coby válečný vysloužilec pak našel štěstí v Poběžovicích. To se jinam hledat nevydal ani Kryštof, syn Jiř́ho Baltazara, narozený roku 1727 a krátce po dvaadvacátých narozeninách pojímající ve svém rodišti za ženu Kateřinu Höphnerovou. Trvalo bezmála dlouhých šestnáct let, než se tomuto páru v západočeském městečku 26. května 1765 narodil chlapec František. ${ }^{33}$

František Regniers/Regner z Bleylebenu (1765-1836) vrátil svou rodinu na úroveň, která jí coby rodině šlechtické náležela. Ve věku třiadvaceti let se ronšperský rodák v blízkém Horšovském Týně oženil s příslušnicí rakouské úřednické nobility Annou Böttcherovou von Peucer (1788), původem z dolnorakouského Rohrau. Zřejmě přímo sňatkem si polepšil natolik, že vzápětí mohl se svou chotí na Domažlicku zakoupit statek Chotiměř s půvabným pozdně barokním zámkem, který si kolem roku 1800 ještě upravil k obrazu svému. František byl také prvním z jakubovské linie Bleylebenů, kdo získal - ovšem jen pro svou osobu, nikoli dědičně - titul říšského svobodného pána (Reichsfreiherr, baron). Ačkoli neznáme jeho profesní kariéru, pracoval zřejmě v některém z pražských úřadů, jelikož v Praze, konkrétně v novoměstském kostele Panny Marie Sněžné, našel i místo

31 https://en.wikipedia.org/wiki/House_of_H\%C3\%A9nin [cit. dne 21. 3. 2020].

32 SOA Litoměřice, pracoviště Děčín, fond RA Thunů, Doerrova genealogická sbírka, sign. VII/859 - Regner von Bleileben. K Evženovi Savojskému zvláště VLNAS, Vít: Princ Evžen Savojský: Život a sláva barokního válečníka. Praha - Litomyšl 2001.

33 SOkA Písek, fond RA Bleylebenů, inv. č. 1 - rodokmen mladší větve Bleylebenů. 
svého posledního odpočinku. ${ }^{34}$ Ve sbírkách Prácheňského muzea v Písku se dochovala malba jeho pohřebního štítu, která ho ovšem tituluje jen jako vlastníka vrchnostenského statku, hospodáře. ${ }^{35}$

František a Anna dali v plodném manželství život osmi dětem, které o rodnou Chotiměř přišly a žily v měštanském prostředí. Ačkoli např. Fridrich se stal uznávaným advokátem a Josef gymnaziálním profesorem až ve vzdáleném ruském (dnes ukrajinském) Chersonu, ${ }^{36}$ mají pro další osudy bleylebenovského rodu hlavní slovo synové Antonín, vrchní finanční rada v Praze, posléze však zakladatel písecké větve, František Ludvík, zakladatel dalmatské větve, a Jan Václav Prokop (1793-1873).

Posledně uvedený žil již od mládí v metropolitní Vídni a pracoval na postu císařského vládního koncipisty. Když ve věku požehnaných osmdesáti let tamtéž umíral, byl již c. k. ministerským radou. ${ }^{37}$ A byl to také Jan Václav Prokop, kdo si nechal v roce 1826 od genealoga Vincenta Ignáce rytíře Seydela vyhotovit rodokmen počínající Alexandrovým bratrem Jakubem a doložený autentickými nebo ověřenými dokumenty, včetně výpisů z prŕíslušných matrik. Na závěr mohl Seydel zkonstatovat, že Jan Václav Prokop je právoplatným rytířem a Jakubovým potomkem v prŕmé linii, ${ }^{38}$ čímž dnešním zájemcům o sestavení bleylebenovského rodokmenu velmi usnadnil práci. Proč tak ale Jan Václav Prokop učinil, zpochybňoval snad někdo jeho urozenost? Vyloučit se to nedá, vždyt' po několik generací Bleylebenové žili jako měštané v zapadlých městech na hranici Čech a Bavorska a šlechtický statek získali až osobou objednavatelova otce. Víme však, k čemu Seydelem vyhotovený rodokmen posloužil. Hned v př́štím roce císař František I., jistě po jeho předložení a přezkoušení, nechal Bleylebenům jejich rytířský stav potvrdit. Stejně učinil o devět let později rovněž jeho nástupce Ferdinand I. ${ }^{39} \mathrm{Od}$ roku 1820 byl Jan Václav Prokop Regner z Bleylebenu ženatý s Karolínou Thomayerovou von Thomar (1798-1838), kterou si vzal ve vídeňském augustiniánském kostele, dvorním chrámu v sousedství Hofburgu. ${ }^{40}$ Byl také prvním Bleylebenem, který se honosil prestižním Leopoldovým rádem (Císařský rakouský řád Leopoldův), založeným císařem Františkem I. na počest jeho otce Leopolda II. a udělovaným širokému spektru zasloužilých osob. Jeho nositel, nejčastěji přední úředník nebo důstojník, současně s udělením získával i titul tajného rady a možnost požádat o přijetí do stavu svobodných pánů/baronů. ${ }^{41}$ Jan Václav Prokop udělal kariéru jako krajský hejtman v rakouském Korneuburgu, později však přešel na ministerstvo vnitra, kde vedl technickou sekci a jako administrativní referent postavil místodržitelství v Herrengasse. Podle svého vnuka měl být velkým milovníkem lovu a častým účastníkem honů v Sierndorfu. Zemřel ve svém domě ve vídeňské Ungargasse. ${ }^{42}$

\footnotetext{
34 SOA Litoměřice, pracoviště Děčín, fond RA Thunů, Doerrova genealogická sbírka, sign. VII/859 - Regner von Bleileben.

35 Prácheňské muzeum v Písku, sbírky, pohřební štít Františka Regnera z Bleylebenu (1765-1836). Za zprostředkování děkuji Mgr. Janu Koubovi.

36 SOA Litoměřice, pracoviště Děčín, fond RA Thunů, Doerrova genealogická sbírka, sign. VII/859 - Regner von Bleileben.

37 Ottův slovník naučný, IV, s. 163.

38 SOkA Písek, fond RA Bleylebenů, inv. č. 1 - rodokmen mladší větve Bleylebenů.

39 VAVŘíNEK, Karel: Almanach českých šlechtických a rytířských rodů 2008. Brandýs nad Labem 2007, s. 331.

40 SOkA Písek, fond RA Bleylebenů, inv. č. 1 - rodokmen mladší větve Bleylebenů.

41 LOBKOWICZ, František: Encyklopedie řádů a vyznamenání. Praha 1995, s. 125-126.

42 Knihovna Prácheňského muzea v Písku, sign. PK 12918, REGNER VON BLEYLEBEN, O.: Lebensaufzeichnungen, s. 1 .
} 
Jan Václav Prokop měl několik potomků, především pak dva syny, kteří založili další svébytné bleylebenovské linie, uherskou a brněnskou. Rytířem Leopoldova řádu se roku 1884 stal i Theodor Antonín Václav, nejstarší syn Jana Václava Prokopa Bleylebena. ${ }^{43}$ Roku 1846 se v Budapešti oženil s Annou Szalayovou a jejich děti pak žily většinou v Uhrách a měly i uherská jména (Ludvík, Béla, Géza, Arpád, Koloman aj.). ${ }^{44}$ Theodor se do Uher přestěhoval hned po absolvování Theresiana, věnoval se soudnictví a dotáhl to až na prezidenta nejvyššího soudního dvora. Vydal dokonce i mad'arskou gramatiku a doma mluvil výhradně mad'arsky. ${ }^{45}$

Theodorův mladší bratr Alfréd František Jiří (1827-1909), dvorní rada, se narodil v rakouském Korneuburgu poblíž Vídně. ${ }^{46}$ Vystudoval práva a sloužil státu při komorní prokuratuře ve Vídni, ${ }^{47}$ ale bližší mu byla mohutně se tehdy rozvíjející technika, která se mu stala již coby profesorovi Německé vysoké školy technické v Brně, založené roku $1849,{ }^{48}$ životní vášní a povoláním. Specializoval se na obor obchodního a také železničního práva, a to až do roku 1898, načež byl opakovaně zvolen rektorem brněnské školy a získal i titul dvorního rady. ${ }^{49}$ Alfréd František Jiří, budovatel honosné rodinné vily v Brně-Jundrově (1865), kde byl členem obecního výboru a kde také zemřel, dal život dvěma mimořádně významným osobnostem z bleylebenovského rodu, Rudolfu Alfrédovi a mladšímu Oktaviánu Alfrédovi. Pět let po jeho smrti po něm byla pojmenována hlavní jundrovská komunikace, v letech 1914-1919 Alfred Regner Ritter von Bleyleben-Strasse, posléze Masarykova a nyní Veslařská.

Celým jménem Rudolf Alfréd Jakub Maria Regner z Bleylebenu (1860-1938) se svým rodičům narodil v Brně, kde také absolvoval gymnázium. V otcových šlépějích vystudoval práva na univerzitě v Praze, načež se vrátil do rodného města a začal pracovat jako zaměstnanec moravského zemského soudu. Již po pěti letech však přešel do Vídně na ministerstvo spravedlnosti, kde se postupně vypracoval až na ministerského radu (1899). Pole jeho působnosti přitom bylo vskutku široké, od administrativních záležitostí vrchního pražského a brněnského soudu přes trestní a vězeňské záležitosti až po oblast tisku. Osm let před vypuknutím první světové války dostoupila Bleylebenova kariéra vrcholu, když se stal, a i během celé války zůstal prezidentem brněnského Vrchního zemského soudu pro Moravu a Slezsko. Na svou hrud' si připnul jak Ř́d Železné koruny třetí trrídy, tak i Leopoldův řád, v čemž napodobil svého dědečka. Rovněž Rudolf Alfréd byl c. k. tajným radou, od roku 1918 také členem státního soudního dvora. ${ }^{50}$ Nejvyšší poctou pro tohoto císařského nadporučíka v záloze jistě bylo udělení velkokříže Řádu Františka Josefa

\footnotetext{
43 Srovnej Ottův slovník naučný IV, s. 163.

44 VAVŘínEK, K.: Almanach, s. 332.

45 Knihovna Prácheňského muzea v Písku, sign. PK 12918, REGNER VON BLEYLEBEN, O.: Lebensaufzeichnungen, s. 2 .

46 SOA Litoměřice, pracoviště Děčín, fond RA Thunů, Doerrova genealogická sbírka, sign. VII/859 - Regner von Bleileben.

47 Knihovna Prácheňského muzea v Písku, sign. PK 12918, REGNER VON BLEYLEBEN, O.: Lebensaufzeichnungen, s. 2 .

48 Podrobně o škole a jejích významných učitelích ŠIŠMA, Pavel: Učitelé na německé technice v Brně 1849-1945. Praha 2004.

49 Knihovna Prácheňského muzea v Písku, sign. PK 12918, REGNER VON BLEYLEBEN, O.: Lebensaufzeichnungen, s. 2 .

$50 \quad$ Kol. aut.: Biografický slovník českých zemí, 5. Praha 2006, s. 566.
} 
v roce $1913 .{ }^{51}$ Po skončení první světové války a vzniku Československa se již výrazněji neangažoval a zemřel ve věku osmasedmdesáti let v Brně.

Jeho o šest let mladšího bratra Oktaviána Alfréda Václava Bohuslava (1866-1945) můžeme směle označit za nejvýznamnějšího a nejproslulejšího příslušníka svého rodu, za muže, který by si jistě zasloužil vlastní monografii. Potenciální životopisec by se přitom mohl opřít o jedinečný pramen, Oktaviánovy strojopisné paměti, v nichž jejich autor detailně líčí svůj život a kariéru. ${ }^{52}$ Oktavián se narodil 23. listopadu 1866 v tehdejší Ovocné ulici č. p. 3 v Brně jako poslední, deváté dítě svých rodičů, z toho osmý chlapec. Léto s rodiči a sourozenci trávil v jundrovské vile a občas se podíval i do Vídně, v níž jeho matka zdědila dům na prestižní adrese v ulici Am Graben (tzv. Trattnerhof, v němž kdysi mimo jiné pobýval slavný skladatel Wolfgang Amadeus Mozart). ${ }^{53}$ Když bylo Oktaviánovi sedm let, jeho rodiče vídeňský dům prodali a ze získaných peněz zakoupili reprezentativní nárožní dům v centru Brna, v jehož prvním patře pak sami bydleli. To už malý Bleyleben navštěvoval základní školu, z níž přešel na brněnské německé gymnázium, na němž studovala většina jeho sourozenců a prríbuzných. A opět - další cesta vedla na právnickou fakultu. Během studií navštívil Oktavián i řadu německých měst a zamířil až do Bruselu, kde pátral po svých předcích Alexandru a Jakubovi, přičemž objevil kupříkladu dokument potvrzující kmotrovství budoucího císařského plukovníka Alexandra Bleylebena. Vedl si také cestovní deník a naučil se francouzsky. ${ }^{54}$ Po odpromování se vrátil do Brna a nastoupil do státních služeb; stal se právníkem v úřadu moravského místodržitelství. Roku 1892 se v pražské Bubenči oženil s Gabrielou Annou Marií Wolfovou z Wachtentreu (1869-1952), dcerou vysokého císařského důstojníka a vnučkou zasloužilého polního maršála. Nedlouho po svých třicátinách přešel z Brna do Vídně na ministerstvo vnitra, kde od roku 1900 vedl prezidiální kancelář a za další dva roky se stal ministerským radou. Bleylebenova píle, nadání a loajalita habsburskému rodu císaři neunikla, František Josef I.v roce 1904 osmatřicetiletého právníka jmenoval zemským prezidentem v Bukovině se sídlem v Černovicích (dnešní Černivci na Ukrajině). Pravdou sice je, že rakouským úředníkům se do vzdálené Bukoviny přiliš nechtělo, nicméně Bleyleben se své funkce zhostil s velkým osobním nasazením. Nejbližšího spolupracovníka našel v bukovinském zemském hejtmanovi Jiřím Wassilkovi von Serecki, společně s nímž se pokusil o všeobecné povznesení této zaostalé okrajové části monarchie a o vzájemné pokojné soužití mnoha zdejších národností a náboženských denominací. S manželkou Gabrielou se pro změnu angažoval v sociální oblasti a stál u vzniku zdejšího ústavu pro hluchoněmé a slepé. Císař František Josef I. jeho zásluhy ocenil nejprve jmenováním do sboru skutečných tajných radů a v roce 1911 povýšením do dědičného stavu svobodných pánů. Ve stejnou dobu potřebovala vídeňská vláda urovnat spory mezi českým a německým etnikem na Moravě a populární Bleyleben, brněnský rodák, se jí jevil jako ideální kandidát na moravského zemského místodržícího. Oktavián se tak vrátil do Brna, ale smírrlivost se tu nestala jeho silnou stránkou, naopak. Jednoznačně se postavil na německou stranu a jakékoli české snahy potlačoval, ba perzekuoval, včetně pokusu o uspořádání sokolské-

VAVŘínEK, K.: Almanach, s. 333.

52 K dispozici jsem měl kopii v knihovně Prácheňského muzea v Písku (sign. PK 12918), kterou muzeu ze Spojených států amerických zaslali potomci rodu Bleylebenů. Za zprostředkování děkuji kolegovi Mgr. Janu Adámkovi.

53 Srov. https://www.geschichtewiki.wien.gv.at/Trattnerhof [cit. dne 18.3. 2020].

54 Knihovna Prácheňského muzea v Písku, sign. PK 12918, REGNER VON BLEYLEBEN, O.: Lebensaufzeichnungen, s. 3-23. 
ho sletu v Brně. Po vypuknutí první světové války se sice na jednu stranu staral o logistické zabezpečení válečného zázemí a o uprchlíky z těžce postižené Haliče, na stranu druhou však stál za další zostřenou perzekucí nespokojenců, za zvýšeným národnostním napětím i drakonickými tresty pro odsouzené na základě stanného práva (mj. známá poprava přerovského Slavomíra Kratochvíla). ${ }^{55}$ V prosinci 1915 na Moravě skončil, ovšem stejnou funkci obratem získal v Dolních Rakousích. Byl jejich posledním místodržícím, po skončení války se i Rakousko přetransformovalo v republiku. Dodnes tu na něho v dolnorakouském Gmündu, přímo na českých hranicích, upomíná Bleylebenova ulice. Během tohoto funkčního období pracoval kuprríkladu na regulaci Dunaje, a uvažovalo se o něm dokonce jako o potenciálním ministrovi vnitra. Císařové František Josef I. i jeho nástupce Karel Oktaviána vyznamenali hned několika čestnými řády. ${ }^{56}$ Po rozpadu habsburské monarchie si stárnoucí a politicky se již neangažující Bleyleben za svůj nový domov zvolil Rakousko, kde žil s chotí nejprve v Badenu u Vídně, posléze v Dietachu poblíž Steyru. Zde také několik měsíců po skončení druhé světové války zemřel. ${ }^{57}$

Ostatní sourozenci takového věhlasu nedosáhli, což ale neznamená, že by mezi nimi nebyli vynikající osobnosti. Jak velela tradice, mnozí (ba většina) nalezli uplatnění v císařské armádě, kde získali vysoké hodnosti a prestižní vyznamenání. Nejkratší čas byl vyměřen nejstaršímu, Edmundu Alfrédovi (1854-1880), poručíkovi u pluku dragounů. Jan Alfréd Jakub Bleyleben (1857-1916) to dotáhl na majora v záloze, zatímco Otto Alfréd Václav (nar. 1859) byl námořním poručíkem a Karel Alfréd Jakub Felix Maria (1862-1916) poručíkem zeměbraneckých dragounů a okresním komisařem. Ani dvojčata Petr a Pavel netvořili výjimku. Petr Alfréd Jakub Jan Cyril Maria (nar. 1864) dosáhl hodnosti nadporučíka a Pavel Alfréd Jakub Jan Metod Maria (1864-1942) dokonce hodnosti generálmajora v záloze. Císař jej v roce vypuknutí první světové války ověnčil Ř́dem Železné koruny třetí třídy s válečnou dekorací a za další dvě léta také Leopoldovým řádem s válečnou dekorací. Po válce pobýval v Brně. ${ }^{58}$ Jan Alfréd Jakub Bleyleben žil v haličském, dnes polském Łańcutu a dal život dvěma synům, staršímu Jiřímu Janu Alfrédovi (nar. 1896) a mladšímu Robertu Karlu Janovi (nar. 1897). Jiří se dal po vypuknutí první světové války k císařskému letectvu a hájil Boku Kotorskou, kde si jako jeden z mála připsal sestřel nepřátelského letounu. Díky tomu, že měl, byt' haličský rodák, domovskou př́íslušnost v Brně, stal se po válce československým občanem a důstojníkem v záloze. Pro armádu už ale nelétal, složil zkoušky pro civilní lety. Na konci 20. let 20. století však zemi opustil a usídlil se ve Vídni. ${ }^{59}$

Oktaviánův jediný syn Maxmilián (1893-1969), který dopsal závěr otcových pamětí s informací o jeho úmrtí, sloužil za první světové války u dragounů, ale do bojů

\footnotetext{
55 O něm zvláště LAPÁČEK, Jiří: Slavomír Kratochvíl, první obět domácího odboje za 1. světové války. In: Sborník Státního okresního archivu Přerov, 22. Přerov 2014, s. 142-199.

56 Vavřínek uvádí: rytíř Rádu Františka Josefa (1899), rytíř Řádu Železné koruny I. třídy (1915), držitel velkokřiže Řádu Rumunské koruny, rytíř ruského řádu s. Stanislava 2. třídy, rytír Řádu Pruské koruny 2. třídy, komtur 1. třídy saského Řádu Albrechtova, velkodůstojník belgického Leopoldova řádu. VAVŘíNEK, K.: Almanach, s. 333 .

57 Kol. autorů: Biografický slovník českých zemí, 5, s. 565-566 a Österreichisches Biographisches Lexikon 18151950, 9. Wien 1988, s. 19.

58 VAVŘ́́NEK, K.: Almanach, s. 332-333.

59 RAJLICH, Jiří: Příslušníci rakousko-uherského letectva z českých zemí. Disertační práce, Filozofická fakulta Univerzity Karlovy. Praha 2018, s. 196.
} 

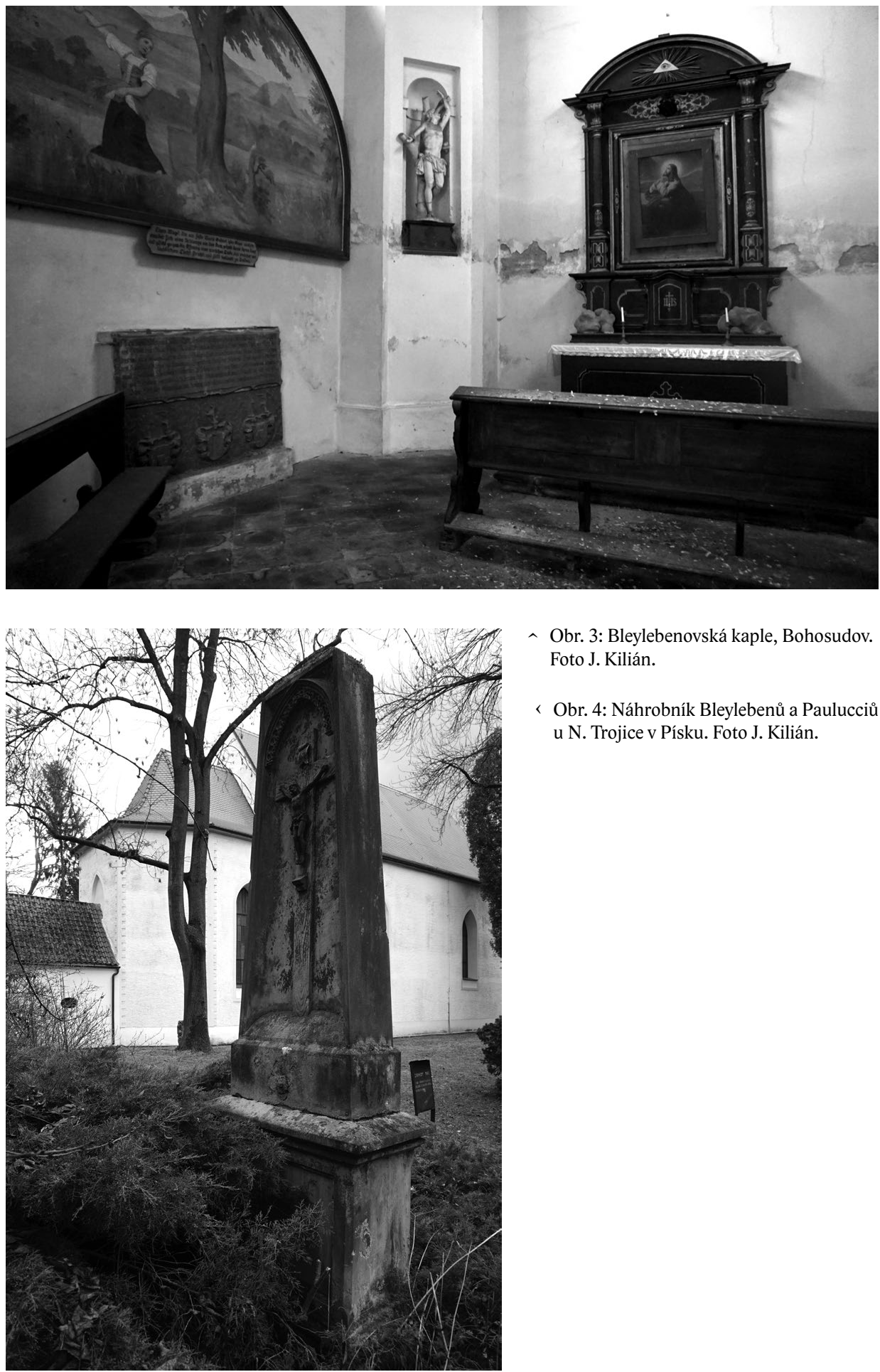

^ Obr. 3: Bleylebenovská kaple, Bohosudov. Foto J. Kilián.

< Obr. 4: Náhrobník Bleylebenů a Paulucciů u N. Trojice v Písku. Foto J. Kilián. 
patrně vůbec nezasáhl. ${ }^{60}$ Po válce se v Lukách nad Jihlavou oženil s Aloisií hraběnkou Widmannovou-Sedlnickou (1894-1977), vnučkou někdejšího rakouského ministra obrany Viktora Widmanna (jenž se po vymření spřízněného rodu Sedlnických z Choltic psal Widmann-Sedlnický) a dcerou posledního německého majitele luckého zámku a panství Antonína Widmanna-Sedlnického. ${ }^{61} \mathrm{~V}$ Lukách, kde Bleylebenova rodina nějaký čas žila, se jim roku 1922 narodil syn Alfréd. Na rozdíl od otce, právníka a politika, i svých strýců - vojáků si Maxmilián zvolil kariéru v dynamicky se rozvíjejícím finančním sektoru a stal se z něj ředitel banky. Po druhé světové válce Moravu opustil stejně jako otec a žil v Rakousku. Zemřel ve Vídni. Co do profese a kariéry jej napodobil zmíněný syn Alfréd, další bankovní ředitel z rodu Bleylebenů. Odstěhoval se však do USA a žil v New Yorku, kde se mu (v roce 1953) narodil syn Peter, jímž potomci císařského proviantmistra Jakuba Bleylebena a brněnské linie pokračují dodnes. ${ }^{62}$

Když Oktavián v mládí pátral po svém příbuzenstvu, narazil i na větev, která žila v polovině 19. století v Rumunsku ve městě Jasy - ale to byla bohužel ojedinělá stopa, po které dále nepátral ani autor těchto řádků. Více se budoucí moravský místodržící dověděl o dalmatské větvi. První tamější Bleyleben, František Ludvík (1795-1854), bratr Jana Václava Prokopa, odešel do vzdálené země za zemědělským podnikáním a stal se velkostatkářem v oblasti Zadaru. Tam se také naplnil jeho osud - byl zastřelen jedním ze svých sloužících přes okno svého domu na Štědrý večer roku 1854. Jeden z Františkových synů měl být finančním komisařem a vůdcem chorvatských demonstrací v době, kdy Oktavián působil na ministerstvu vnitra. Oktaviánův bratr Rudolf Alfréd si s ním dopisoval, když se tento dalmatský př́buzný s úspěchem ucházel o místo ve Strakově šlechtické akademii v Praze. ${ }^{63}$ Další údaje doplnil Oktaviánův syn Maxmilián po své návštěvě v Jugoslávii. Tragicky zesnulý František Ludvík měl dospívající syny Jana (nar. 1835) a Ivana. Jan, narozený v Zadaru, ${ }^{64}$ měl syny Simona a Josefa, Simon syny Zdenka (Zdenko) a Borise. Oba tito muži byli Titovými stoupenci a za německé okupace museli Jugoslávii opustit. Boris měl syna Slobodana, který se narodil počátkem 40. let 20. století v exilu v Egyptě a jímž dalmatská (jugoslávská) linie Bleylebenů rovněž pokračuje do současnosti. ${ }^{65}$

Zrovna tak si Oktavián do svých pamětí poznamenal, že jeden jeho př́buzný pracoval u finančních úřadů v Čechách a měl dceru Klementinu, která prý byla velmi krásná a zatoužil po ní i císař. To měl ale Oktaviánův otec důrazně popřít (sic!). O úmrtí posledních žen z této linie byl někdejší moravský místodržící informován česky psaným smutečním oznámením. ${ }^{66}$ Oním př́buzným byl jeho prastrýc Antonín, zakladatel písecké větve. ${ }^{67}$

\footnotetext{
60 Knihovna Prácheňského muzea v Písku, sign. PK 12918, REGNER VON BLEYLEBEN, O.: Lebensaufzeichnungen, s. $125,128$.

61 K Widmannům stručně SMUTNÝ, Bohumír: Widmannové a jejich rodinný archiv. Genealogické a heraldické informace 4 (19), 2000, s. 9-14.

62 VAVŘÍNEK, K.: Almanach, s. 334.

63 Knihovna Prácheňského muzea v Písku, sign. PK 12918, REGNER VON BLEYLEBEN, O.: Lebensaufzeichnungen, s. 2. Bohužel není zřejmé, zda šlo o Jana, či o Ivana.

64 VAVŘínEK, K.: Almanach, s. 335.

65 Knihovna Prácheňského muzea v Písku, sign. PK 12918, REGNER VON BLEYLEBEN, O.: Lebensaufzeichnungen, přívěsek.

66 Tamtéž, s. 2.

67 SOA Litoměřice, pracoviště Děčín, fond RA Thunů, Doerrova genealogická sbírka, VII/859 - Regner von Bleileben, nekorektně uvádí, že se v Písku usadil Theodor Antonín, syn Jana Václava Prokopa Bleylebena (sic!), který měl se svou ženou Annou mnoho potomků, mj. dceru Aranku. Theodor Antonín žil totiž se ženou Annou
} 
Antonín Regner z Bleylebenu (1802-1878) se narodil na zámku v západočeské Chotiměři jako zřejmě nejmladší syn Františka a Anny, rozené Böttcherové von Peucer. Jeho oborem se stalo finančnictví a jeho domovem postupně hned několik českých měst, v nichž zastával poměrně významné úřednické funkce. V Plzni byl komisařem při c. $\mathrm{k}$. finanční okresní správě, v Jičíně vrchním finančním radou, v Čáslavi finančním radou a snad i okresním finančním ředitelem. Žil ale také v Praze, kde patřil k zakládajícím členům Spolku na pomoc potřebným dětem (Verein zum Wohle hilfsbedürftiger Kinder) ${ }^{68}$ a kde také 4. ledna 1878 zemřel a o dva dny později byl pohřben na Olšanských hřbitovech. Příčinou úmrtí vrchního finančního rady měl být marasmus, tj. marasmus senilis, kterýmžto latinským termínem bývá označována sešlost věkem. ${ }^{69}$ Podstatné především je, že coby stárnoucího mládence jej osud, či spíše pracovní povinnosti, zavály do jihočeského Písku, kde jej okouzlila mladičká dcera píseckého poštmistra Simoniho Klementina natolik, že se tu v roce 1848, 10. záŕí, za hojné účasti předního píseckého měštanstva s devatenáctiletou dívkou oženil. ${ }^{70}$

Rodina Simoni měla, jak už samo jméno napovídá, italský původ a do Čech se dostala ve druhé polovině 18. století skrze habsburskou armádu. První český Simoni byl kdysi kadetem u císařského pluku a po propuštění ze služby se usadil v Miroticích, kde si získal záhy takovou prestiž, že si jej místní zvolili za svého purkmistra. ${ }^{71}$ František, jeden z jeho potomků, snad syn, ale možná i vnuk, se oženil s Antonií Dipolter z Dippoldiswalde ${ }^{72}$ a zamířil do Písku, kde se stal císařským poštmistrem. Po dceři Klementině se mu ještě narodili synové František Josef Jakub (1831) a Rudolf Robert Josef (1834). František Josef Jakub byl v roce 1854 posluchačem práv na pražské univerzitě: tehdy mu jeho profesor češtiny vystavil osvědčení, že Simoni svou rodnou mateřštinou vládne dokonale a hbitě. ${ }^{73}$ V rodném Písku se stal okresním hejtmanem a ve věku nedožitých třiaosmdesáti let také zemřel, na mrtvici. ${ }^{74}$ Místo posledního odpočinku nalezl na hřbitově u kostela Nejsvětější Trojice.

Mužského potomka se Antonín Regner z Bleylebenu s chotí Klementinou (která ho o mnoho let přežila) nedočkal, pouze čtyř dcer. Nejmladší Alexandrina, narozená v Jičíně, se provdala do Velké Británie, konkrétně do Skotska. ${ }^{75}$ Zajímavou partii získala rovněž Angela Marie Františka, narozená v Čáslavi a provdaná ve farním kostele sv. Otmara

Szalayovou v Uhrách a Aranka jejich dcerou nebyla.

68 SOkA Písek, Archiv města Písek, sign. D II - Bleyleben, kart. 1102. Diplom vystavený v roce 1871 Antonínu Regnerovi coby zakládajícímu členovi Spolku na pomoc potřebným dětem (Verein zum Wohle hilfsbedürftiger Kinder) v Praze.

69 SOkA Písek, fond RA Bleylebenů, inv. č. 1 - úmrtní list Antonína Regnera.

70 Oddací osvědčení sepsané na děkanském úřadu v Písku 10. června 1874 - potvrzuje se v něm, že Antonín Regner rytíř z Bleylebenu, komisař při c. k. finanční okresní správě v Plzni, je manželským synem Františka Regnera z Bleylebenu, pozemkového majitele v Klatovském kraji, a Anny Regnerové, rozené Böttcherové z Peucer, původem z Rohrau v Dolních Rakousích, a že si v Písku 10. září 1848 vzal Klementinu Simoni, dceru Františka Simoniho, píseckého poštmistra, a jeho ženy Antonie Dipolter z Dippoldisswalde.

71 SOkA Písek, fond RA Bleylebenů, inv. č. 1 - osobní doklady členů rodiny Regner von Bleyleben, Simoni a Paulucci delle Roncole.

72 Tamtéž - úmrtní list Antonie Simoniové.

73 Tamtéž - osobní doklady členů rodiny Regner von Bleyleben, Simoni a Paulucci delle Roncole.

74 Tamtéž - úmrtní list Františka Simoniho. Zemřel 19. prosince 1913 ve věku 82 let a 9 měsíců, pohřben byl 22. téhož měsíce u kostela Nejsvětější Trojice.

75 KOUBA, Jan: Dva př́běhy jedné Alexandriny : Život a pozůstalost písecké šlechtičny Aranky Alexandriny Regner von Bleyleben. In: Prácheňské muzeum v Písku v roce 2007. Písek 2008, s. 74. 
ve Vídni roku 1892 za Antonína, markýze Paolucci delle Roncole, rodáka z italských Benátek a toho času císařského majora sloužícího v Tyrolsku. ${ }^{76}$ Paolucci, posléze plukovník, žil se svou ženou v Písku, ale zemřel pouhých deset let po vídeňském sňatku, ${ }^{77}$ aniž měl se ženou nějaké děti. To ovšem platilo rovněž pro Alexandrinu a také pro další ze sester, takže jedinou vnučkou Antonína Regnera - a současně posledním výhonkem písecké větve bleylebenovského rodu - se stala nemanželská dcera nejstarší Klementiny, narozená ve stejném roce (1878, ovšem až koncem prosince), ve kterém její dědeček zemřel.

Uvedená Klementina je onou krásnou ženou z pamětí moravského místodržícího Oktaviána Bleylebena. Zda skutečně vzbudila žádostivost i u císaře Františka Josefa I., se stěží kdy podaří potvrdit či vyvrátit, může se jednat jen o dobový drb. Podle zjištění píseckého badatele Jana Kouby, zatím nikde nepublikovaného, však byl jejím otcem jiný člen habsbursko-lotrinské dynastie - arcivévoda Vilém František Karel (1827-1894), voják, který nakonec zemřel na následky pádu z koně. ${ }^{78} \mathrm{~K}$ dítěti se ovšem otec neznal, jeho matku si za ženu nevzal (šlo by o velmi morganatický sňatek), takže ta svou malou dceru dala na výchovu pěstounům do tyrolského Kufsteinu a sama se na dlouhý čas uchýlila do ústavu šlechtičen ve Štýrském Hradci. Zřejmě až v průběhu první světové války se vrátila do Písku, kde si od listopadu 1916 pronajímala od píseckého obchodníka Emanuela Fröhlicha byt v prvním patře jeho domu. Šlo o dva pokoje a kuchyň bez kamen, a to za čtvrtletní nájemné ve výši 480 korun. ${ }^{79}$ Dožívala tedy ve velmi skromných poměrech. ${ }^{80}$

Její dceři Arance Alexandrině (1878-1944), která svého otce nikdy nepoznala, zůstalo matčino jméno, Regnerová z Bleylebenu. ${ }^{81}$ I ona měla velmi pohnutý, zpočátku snad až divoký život, jenž vyvrcholil sňatkem s údajným (neznámým) švýcarským šlechticem, který ale zmizel ve víru první světové války. Postupně přicházela i o další příbuzné, takže nakonec zůstala jen ona a teta ve vzdáleném Skotsku. Její urozený, leč nemanželský původ se stal terčem pro jistého vyděrače, který poukazoval na luxusní život jedné prohabsburské (a to jistě ještě netušil, že v jejích žilách dokonce koluje habsburská krev) „,bastardky“ ve městě Písku. Ovšem Aranka sama se tehdy teprve čerstvě dověděla o svém původu a možná i to podnítilo její další zájem o rodinnou minulost a o sbírání bleylebenovských památek. Pátrala i po svých pěstounech z rakouského Kufsteinu. Kvůli svému původu vedla zpočátku dvojí život a vydávala se za svou skotskou tetu, ve 20. letech 20. století už však byla Arankou Alexandrinou Regnerovou. A přes to, že ji teta lákala do Británie a starý rodinný přítel do Vídně, zůstala v maloměstském Písku. Nouzí tu rozhodně netrpěla, a to

\footnotetext{
76 SOkA Písek, fond RA Bleylebenů, inv. č. 1 - oddací list Angely Bleylebenové a Antona Paolucciho. Potvrzení sňatku ve Vídni 26. 9. 1892, kdy se vzali Angela Marie Františka Regnerová z Bleylebenu, bydlící v Písku na Budějovickém předměstí, a Anton markýz Paolucci delle Roncole, narozený v Benátkách, toho času císařský major sloužící v Tyrolsku. Nevěsta se narodila v Čáslavi Antonínu Regnerovi, čáslavskému finančnímu radovi, a Klementině rozené Simoni. Viz také tamtéž - svatební oznámení. Klementina, rozená Simoni, vdova po Antonínu Regnerovi z Bleylebenu, oznamuje, že její dcera Angela si v září 1892 ve farním kostele sv. Otmara ve Vídni vezme Antona Paolucciho.

77 Tamtéž - osvědčení o řádném chování. Vydal je děkanský úřad Písek 18. července 1903 pro Angelu, jejíž manžel zde v Písku zemřel 14. prosince 1902 už ve funkci plukovníka.

78 Za informaci o údajném otcovství také děkuji prímo Mgr. Janu Koubovi.

79 SOkA Písek, fond RA Bleylebenů, inv. č. 1 - nájemní smlouva Klementiny Regnerové z Bleylebenu (1916).

80 Je ale možné, že se na sklonku svého života ještě provdala. Srovnej: tamtéž - usnesení okresního soudu v Písku z roku 1928. Mluví se zde o udržování hrobu (rodinné hrobky) Klementiny Sedláčkové (Regnerové?) u kostela Nejsvětější Trojice. V píseckém kostele sv. Kř́že se za ni a její rodinu měla navíc z její finanční pozůstalosti v Městské spořitelně v Písku sloužit každoročně na den 30. října mše.

81 Viz např. její cestovní pas is dochovanou pasovou fotografií. SOkA Písek, fond RA Bleylebenů, inv. č. 1.
} 
ani nouzí o nápadníky - díky dědictví po příbuzenstvu na tom byla velmi solidně. Podruhé už se ovšem neprovdala, i proto, že se ozval svědek jejího švýcarského sňatku s tím, že smrt jejího manžela dosud není potvrzená a mohlo by tedy jít o bigamii. Když sepsala závět', několikrát ještě upravovanou, určila svůj dům městu, aby z jeho pronájmu vydržovalo sirotčinec, a mnohé cennosti a kuriozity píseckému (tehdy Městskému) muzeu. Seznam věcí odevzdaných této pamětové instituci po její smrti zahrnoval šestasedmdesát položek. Mimo ty muzeum posléze po Arance získalo ještě jeden stříbrný svícen a několik uměleckých předmětů, které se musely nejdřive ocenit. Součástí odkazu byly předměty denní potřeby, kuchyňská výbava, ale také rodové insignie (typář, brož s erbovní iniciálou, malby pohřebních štítů), nábytek či drobné rodinné památky (fotografie apod.). Po roce 1945 celistvost pozůstalosti utrpěla několika ranami, i dnes však tvoří významnou součást muzejních sbírek. ${ }^{82}$ Pozůstalost písemná, rozšiřrená o dokumenty rodů Simoni a Paolucci, naopak putovala do píseckého okresního archivu, kde se z ní stal fond Rodinný archiv Bleylebenů. ${ }^{83}$

\section{Závěrem}

Někdy na přelomu 16. a 17. století se dva příslušníci nižší nizozemské šlechty, Alexandr a Jakub Regniersové z Bleylebenu, rozhodli pro kariéru v habsburských službách ve středoevropské monarchii, oba patrně v armádě. $\mathrm{V}$ roce 1610 získali společně od císaře Rudolfa II. potvrzení svého šlechtického stavu a někdy v té době se také usadili v Čechách. Starší a úspěšnější Alexandr se oženil s Annou Marií Pichlovou z Pichelberka a žil v Praze, kde jej zastihlo české stavovské povstání, které katolickou rodinu donutilo uprchnout do exilu. Bleyleben od těchto počátků třicetileté války bojoval pod císařskými prapory, posléze ve vojsku Albrechta z Valdštejna. Postupně se od nižších hodností vypracoval až na plukovníka a dvorského válečného radu. Z konfiskací českým rebelům získal reprezentativní dům v Praze na Malé Straně a dvě severočeská panství, císař jej navíc za zásluhy povýšil do stavu svobodných ř́šských pánů, baronů. Jeho jediný syn Karel Maxmilián, velmi neklidného a násilnického charakteru, byl zabit v roce 1648 při konfliktu se saskými vojáky, otec zemřel o rok později. Ovdovělá Anna Marie pak pečovala o rodinný majetek, který se jí po třicetileté válce podařilo konsolidovat, a věnovala značné finanční prostředky na zbožné účely. Především díky její fundaci vznikl významný poutní areál v severočeském Bohosudově.

Alexandrův bratr Jakub sice takového postavení jako starší sourozenec nikdy nedosáhl a žil po třicetileté válce ve skromných podmínkách v německém městě Furth im Wald, ale založil rodovou linii, která existuje do dnešních dnů. Jeho potomci se do Čech vrátili v průběhu 18. století, nejprve do Poběžovic (které jim ovšem nepatřily), pak do Chotiměře, kde už získali (konkrétně František Regniers/Regner z Bleylebenu) vlastní panství i s důstojným zámkem. Znovu se zařadili mezi šlechtu habsburských zemí, dosáhli na baronský titul a vládnoucí garnituře sloužili nejčastěji jako úředníci, právníci a vojáci. V 19. století se rozštěpili hned do čtyř větví - brněnské, písecké, dalmatské a uherské. Theodor Antonín Václav Bleyleben se stal dokonce prezidentem uherského nejvyššího soudního dvora a autorem mad'arské gramatiky. Dalmatská linie se věnovala zemědělskému podnikání a angažovala se za druhé světové války ve prospěch Titovy Jugoslávie.

82 KOUBA, J.: Dva př́běhy, s. 72-80.

83 SOkA Písek, fond RA Bleylebenů, 1 karton, inv. č. 1-5. 
Theodorův mladší bratr Alfréd František Jiří se stal uznávaným profesorem na německé vysoké škole technické v Brně a stavitelem rodinné vily na okraji moravské metropole, v ulici, která posléze nějaký čas nesla jeho jméno. Život dal osmi synům, z nichž většina se uplatnila ve vojenství - s výjimkou dvou nejproslulejších. Rudolf Alfréd se stal prezidentem brněnského Vrchního zemského soudu pro Moravu a Slezsko a nositelem celé řady vyznamenání. Nejzářivější postavou mezi Bleylebeny byl ovšem jeho nejmladší bratr Oktavián Alfréd, přední habsburský politik a diplomat éry začátku 20. století. Byl postupně jmenován zemským prezidentem v Bukovině, moravským místodržícím v Brně (do 1915) a místodržícím v Dolních Rakousích. V hlavním městě Bukoviny, dnes ukrajinském Černivci, usilovně podporoval hospodářský, společenský a kulturní rozkvět země. Naopak na Moravě bohužel neblaze proslul perzekucí českých patriotů a po vypuknutí první světové války drakonickými tresty vůči nespokojencům. Je také autorem rozsáhlých pamětí, které po jeho smrti dokončil jeho syn Maxmilián, povoláním právník a ředitel jedné z bank ve Vídni. Jeho potomek přesídlil do USA, kde žijí Bleylebenové dodnes. Naproti tomu česká, písecká větev na sklonku druhé světové války vymřela Arankou Alexandrinou Regnerovou z Bleylebenu, která odkázala mnohé rodinné památky píseckému muzeu a vytvořila i menší rodinný archiv, v současnosti uchovávaný v píseckém okresním archivu.

\section{Summary}

\section{The Bleylebens - a Dutch family in History and Culture of the Habsburg monarchy}

Around the turn of the $16^{\text {th }}$ and $17^{\text {th }}$ centuries, two members of the lower Dutch nobility - Alexander and Jakub Regniers of Bleyleben decided to pursue careers in the service of the Central European Habsburg monarchy, both probably in the army. In 1610, they received confirmation of their aristocratic status from Emperor Rudolf II and around that time, they also settled in Bohemia. The older and more successful Alexander married Anna Maria Pichlová of Pichelberk and lived in Prague where he was caught in the Bohemian Revolt which forced the Catholic family to flee into exile. Since the beginning of the Thirty Years' War, Alexander Bleyleben fought in the imperial battalions and later in the army of Albrecht von Wallenstein. He gradually worked his way up from lower ranks to colonel and became a member of the Hofkriegsrat. He later acquired a prestigious house in Malá Strana in Prague and two estates in North Bohemia which had been confiscated from Czech rebels. Furthermore, based on his merits, the emperor promoted him to the rank of Freiherr, baron. His only son Karel Maxmilián, a man of a very restless and violent character, was killed in 1648 in a conflict with Saxon soldiers. Alexander died a year later. The widowed Anna Marie then took care of the family property which she managed to consolidate after the Thirty Years' War. She also donated considerable funds to the Church. An important pilgrimage site was established in Bohosudov, North Bohemia, mainly thanks to her patronage.

Although Alexander's brother Jakub never came close to the positions held by his older brother and lived in humble conditions in the German town of Furth im Wald after the Thirty Years' War, he established a family line that exists to this day. His descendants returned to Bohemia in the $18^{\text {th }}$ century, first to Poběžovice (which did not belong to them) and later to Chotiměr where they had already acquired (specifically František Regniers/Regner of Bleyleben) their own estate with a respectable château. They rejoined the nobility of the Habsburg lands, received the title of baron and served the Habsburgs most often as clerks, lawyers, and soldiers. In the $19^{\text {th }}$ century, they split into four branches - Brno, Písek, Dalmatian and Hungarian. Theodor Antonín Václav Bleyleben even became the president of the Hungarian Supreme Court and wrote the Hungarian grammar. The Dalmatian line focused on agriculture and was involved in the Second World War on the side of Tito's Yugoslavia. Theodor's younger brother Alfréd František Jiří became a respected professor at the German Technical University in Brno 
and built the family villa on the edge of the Moravian metropolis, in a street that later bore his name for some time. He had eight sons, most of whom worked in the military-except for the two most famous ones. Rudolf Alfréd became the president of the Brno Higher State Court for Moravia and Silesia and received and number of awards. However, the most significant figure among the Bleylebens was his youngest brother Octavian Alfred, a leading Habsburg politician and diplomat of the early $20^{\text {th }}$ century. He was appointed President (District-Governor) in Bukovina, Moravian stadtholder in Brno (until 1915) and stadtholder in Lower Austria. In the capital of Bukovina, today's Ukrainian Chernivtsi, he strongly supported the economic, social and cultural prosperity of the country. In Moravia, however, he became notorious for the persecution of Czech patriots and after the outbreak of the First World War, for draconian punishments against dissidents. Furthermore, he wrote extensive memoirs completed after his death by his son Maximilian, a lawyer by profession and director of one of Vienna's banks. His descendant moved to the USA where the Bleylebens live to this day. On the other hand, at the end of the Second World War, the Czech Písek branch of the family died out and the last remaining BleylebenAranka Alexandrina Regner of Bleyleben bequeathed many family possessions to the Pisek Museum and created a small family archive which is currently kept in the Pisek district archive.

\section{Přiloha}

Rodokmen rodu Bleylebenů - viz následující strana 